\title{
Methodical approach to the assessment of housing-and-communal services management
}

\author{
Asiiat Mottaeva ${ }^{1, *}$ \\ ${ }^{1}$ Moscow State University of Civil Engineering, 129337, 26, Yaroslavskoye Shosse, Moscow, Russia
}

\begin{abstract}
The objective of this research is the development of methodical approach to the assessment of the quality of housing-and-municipal services management for the formation of the mechanism of effective functioning and development of the organizations in the housing-andmunicipal complex of the city and of the country in general in modern conditions. The author offers an integrated approach to the assessment of quality of housing-and-communal services management. The five-criteria functional model, which allows observing in what directions the priority improvements of the control system are necessary, is also created by the author. The results of the research can be used by regional and municipal authorities, as well as by the heads of organizations working in the sphere of housing-and-communal services in order to form the mechanism of optimum management of the development of this industry, of the assessment of its efficiency, and justification of sources of its financing.
\end{abstract}

\section{Introduction}

The nature of the organizational-and-economic relations both between enterprises and organizations, and between them and municipal authorities has thoroughly changed in the conditions of the current of market mechanisms and formation of local self-government in our country. But all the transformations in the housing sector did not give the expected results. These and many other circumstances cause the need of studying and judgment of the processes happening in the sphere of housing-and-communal services in modern conditions.

The matters of the development and improvement of the sphere of housing-andcommunal services, are considered in works of Avdeev V.V., Basin E.V., Bychkovsky I.V., Valdaytsev S.V., Dronov A.A., Kuznetsov Yu.V., Kruglik S.I., Mintz I.G., Potemkin V.K., Prigarin by B.C., Rybakova F.F., Sigova I.I., Talonova A.V., Chekalina B.C., Chernysheva J.H., Shamuzafarova A.Sh. and others. Scientific works published by Voronin A.G., Ivanova V.N., Kirpichnikov V. A., Oshurkov A.T., Rokhchin V.E., Shirokova A.N., Yurkova S.N., D. Maslov and some other authors rather fully describe the essence, contents and current problems of local self-government, which are studied by the author within the research $[1,2,3,4]$. But those works do not raise many questions of housing-andcommunal services management, in particular, they do not help to carry out the complex

* Corresponding author: angela-1309.m@yandex.ru 
assessment of housing-and-communal services quality. Therefore, the research in this area remains very relevant.

\section{Methods and Principles}

The methodological basis of the research is made by dialectic approach to studying of the phenomena and processes in social-and-economial systems, taking into account some regularities and features of the development of the social sphere. Methods of the economic analysis, comparative, monographic, sociological poll, methods of expert estimates, economic-mathematical methods were also used while carrying out this research.

The main objective of the assessment of management quality consists in the identification of how the characteristics of the chosen model of management meet the requirements of the services consumers. The author believes that the following principles have to be the cornerstone for the estimation of the management quality [5]:

- orientations to the consumers (the need of carrying out analysis of satisfaction of the consumers of services);

- scientific validity (the assessment is based on the evidence-based provisions, methods and scientific approaches) [6];

- complexity of estimates of quality (judgment of management quality has to be multilateral, considering signs and properties, expressing the separate parties of quality of this type of activity);

- systemacities (is defined by quality of the elements entering a control system (the purpose, tasks, the principles, methods, technologies, etc.);

- combinations of the quantitative and qualitative analysis (both quantitative, and qualitative methods and estimates are applied) [6];

- continuity and staging of implementation of estimates (the assessment has to be continuous process and be present at all the stages of performance of administrative works); - constant self-assessment of management from the organization (dynamism of factors of external and internal environments, need of timely identification of the happening changes and correction of administrative activity taking into account the obtained information) [7];

- improvement (identification of strengths and weaknesses of management and opportunities of the improvement of the organization activity) [8].

The assessment of quality of management of housing-and-communal services cannot come down only to the certain function, which is carried out by official administrative bodies, but it is a complex group activity in which the representatives of the regional executive authority of the region, municipal authorities and also subjects of private business take part. Therefore, the quality of management of housing-and-communal services should be considered from the following positions:

- federal and municipal authorities (ensuring safety and development of the housing stock and municipal services) [9];

- representatives of business (profitable functioning of the enterprises);

- population (high quality of services on the basis of socially oriented tariffs) [10].

The author starts from the functional model of the self-assessment of management, offered by D. Maslov, for the assessment of elements of the control system. The assessment of quality of the elements of the control system was carried out using the example of the managing company Vostochnaya in St. Petersburg.

\section{Results}

The author of this work offers an integrated approach to the assessment of quality of 
management of housing-and-communal services (Figure 1).

\begin{tabular}{|c|c|}
\hline \multicolumn{2}{|c|}{ 1. Assessment of management of housing-and-communal services: } \\
\hline $\begin{array}{l}2 \text { Assessment of } \\
\text { the regional level } \\
\text { of management }\end{array}$ & $\begin{array}{l}2.1 \text { The analysis of the performance and development of } \\
\text { housing-and-communal unilities in the region in general (methods } \\
\text { of retrospective, structural and comparative analysis); } \\
2.2 \text { Analysis of the organizational forms of managemant of } \\
\text { housing-and-communal utilities (methods of retrospective, } \\
\text { comparative analysis); } \\
2.3 \text { Analysis of regional target programmes (descriptive } \\
\text { method); } \\
2.4 \text { Analysis of regional standards of cost of housing-and- } \\
\text { communal services (methods of the comparative, structural, } \\
\text { factorial analysis); } \\
2.5 \text { Analysis of the experience of application of public-and- } \\
\text { private partnership in the regions of the Russian Federation } \\
\text { (descriptive method); } \\
2.6 \text { Analysis of the use of public-and-private partnership in the } \\
\text { region (methods of descriptive and comparative analysis); } \\
2.7 \text { Analysis and distribution of the experience of the use of } \\
\text { innovative technologies for the housing-and-communal utilities } \\
\text { (methods of descriptive, comparative analysis). }\end{array}$ \\
\hline $\begin{array}{l}3 \text { Assessment } \\
\text { of the municipal } \\
\text { level } \\
\text { management }\end{array}$ & $\begin{array}{l}\text { 3.1 Analysis of performance and development of housing-and- } \\
\text { communal utilities in the municipal unit (methods of retrospective, } \\
\text { structural and comparative analysis); } \\
3.2 \text { Analysis of performance of normative legal acts of the } \\
\text { Russian Federation and territorial subject of the Russian Federation } \\
\text { (descriptive method); } \\
\text { 3.3 Analysis of municipal development programmes of } \\
\text { housing-and-communal utilities (descriptive method); } \\
3.4 \text { Analysis of the experience on the implementation of } \\
\text { investment projects (methods of comparative analysis); } \\
3.5 \text { Analysis of the experience of the implementation of } \\
\text { resource-saving technologies (methods of retrospective and } \\
\text { comparative analysis); } \\
\text { 3.6 Analysis of readiness of the housing stock by winter } \\
\text { (descriptive method) } \\
\text { 3.7 Analysis of the managing organizations work }\end{array}$ \\
\hline $\begin{array}{l}4 \text { Assessment } \\
\text { of management in } \\
\text { the organizations of } \\
\text { housing-and- } \\
\text { communal services }\end{array}$ & $\begin{array}{l}\text { 4.1 Analysis of the economic and financial condition of the } \\
\text { enterprises (methods of the comparative, structural, factorial } \\
\text { analysis); } \\
4.2 \text { Analysis of quality of services (method of comparative } \\
\text { analysis, poll, questioning); } \\
\quad 4.3 \text { Analysis of satisfaction of consumers (polls, questioning) }\end{array}$ \\
\hline
\end{tabular}

Fig. 1. Technique of complex assessment of management in the sphere of housing-and-communal services 
The general performance of the system of management of the organization is reflected by the graphic representation of the performance of the criterion "communication" ("a communication profile"). The pentagram is created taking into account the results of the expert assessment in points for each of five estimated criteria of the functional model (Figure 2). Such approach allows observing in what directions the priority improvements of the control system are necessary [11].

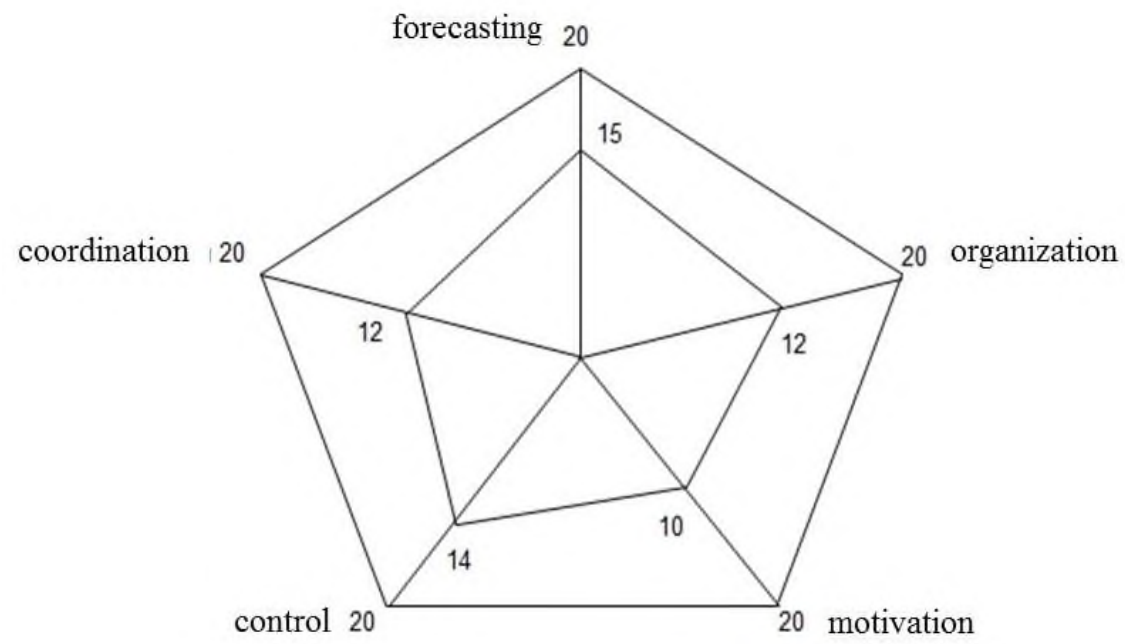

Fig. 2. Communication profile of managing company

Thus, according to Figure 2, it is possible to conclude that the lowest mark in 10 points for the criterion "motivation" means that this direction needs the additional analysis and improvement.

According to this technique, the assessment can be carried out not only by the heads of the organization but also by ordinary employees. At the same time, the assessment made by the heads (Ah) for each of the five criteria and the general assessment are compared to the corresponding assessment made by employees (Ae), and then the adequacy of management coefficient (Kam) is calculated according to the formula:

$$
\mathrm{Kam}=\frac{A h-A e}{4}
$$

where Kam - management adequacy ratio;

$\mathrm{Ah}$ - average assessment by the heads;

Ae - average assessment by the employees;

4 - the greatest possible assessment for the category.

Three zones of adequacy are applied for the analysis of the coefficient of adequacy of management.

1. Zone of adequate assessment of the management opportunities $(-0,1 \leq 0 \leq 0,1)$. Indicators of this zone characterize the adequate perception of management decisions by the employees, administration and the stuff are guided by the identical principles in their work; that contributes to the harmonious development of the organization. The heads, using such situation, have the opportunity to improve the business process constantly.

2. Zone of underestimation of the management opportunities (1-0.1). Indicators of the zone reflect insufficient leadership skills of managers of the enterprise. There are potential 
opportunities for the improvement of the control system. Employees estimate the activity of the enterprise higher, than the heads do. It is necessary to use this situation for the correction of the position of administrative personnel and for the activization of processes of the improvement.

3. Zone of overvaluation of the management opportunities $(0.1<1)$. Indicators of the zone of over valuation reflect the divergences of opinions of the heads and employees on the situation in the enterprise. In this case, the majority of management decisions can face the internal resistance of the stuff, and any transformations, initiated by the management will be absolutely inefficient. Management priorities are the following:

- identification of the reasons of discrepancies, analysis of categories where the maximum divergences in the assessment are traced;

- establishment of closer contact with the personnel;

- definition of the degree of satisfaction of the personnel;

- strengthening of the corporate culture.

Thus, the use of expert methods allows to consider individual opinions of the qualified specialists, who are the understanding the matter best. However, the subjective analysis is capable to introduce the element of conscious or unconscious distortion of estimates in connection with the personal interest of the subject analyzing quality of management.

\section{Discussion}

It is impossible to underestimate the role of the state, regional and municipal authorities for the improvement of housing-and-communal services management.

For the purpose of the increase in the overall performance in the sphere of granting housing-and-communal services on the prevention of violation of the rights of consumers such bodies as Rospotrebnadzor and State Housing Inspectorate have to interact, and the joint checks, regular exchange of information, transfer of addresses of consumers on accessory have to be the main forms of such interaction. Thanks to such interaction, it is possible to assert the legitimate rights of citizens when receiving housing-and-communal services, to increase the level of security of consumers from actions of unfair performers at their rendering to reduce social tension in society more effectively.

\section{Conclusion}

According to the results of the research, the author's technique of assessment of quality of management in the organizations is offered. Three groups of criteria make up the basis of the technique:

- the criteria, characterizing the result of management;

- the criteria, characterizing the management efficiency;

- the criteria, characterizing the quality of elements of the control system.

The assessment of quality of housing-and-communal services management as a complex group activity in which representatives of the regional executive authority of the region, municipal authorities and also subjects of private business take part, has been carried out. The integrated approach to the assessment of quality of housing-and-communal services management, uniting various subjects of management with the use of both quantitative and qualitative methods of the research has been offered in the work. This technique is based on the following principles: orientation to the consumer; scientific validity; complexity of estimates of quality of management; systematicity; combination of the quantitative and qualitative analysis; continuity of the implementation of estimates; constant self-assessment of management from the organization; improvement. 
The point system is the cornerstone of the self-assessment technique with the use of the functional model, and it allows managers to compare the current results and the standard or indicators of other organizations, and also to trace the dynamics of improvements, when carrying out the repeated self-assessment.

\section{References}

1. S. Amelchugov, A. Klimov, O. Mickevich, O. Nikitina, MATEC Web of Conferences, 245(4), 03008 (2018), DOI: 10.1051/matecconf/201824503008

2. O. Skripnik, IOP Conference Series Earth and Environmental Science, 90(1), 012145 (2017) DOI: 10.1088/1755-1315/90/1/012145

3. S. Okhotina, P. Kukhtin, L. Manukhina, MATEC Web of Conferences, 106, 08074 (2017) DOI: 10.1051/matecconf/201710608074

4. V. Teplyshev, R. Petrosyan, D. Spitsov, M. Pushkareva, MATEC Web of Conferences, 193(4), 05079 (2018) DOI: 10.1051/matecconf/201819305079

5. Eurofound, Third European Quality of Life Survey - Quality of life in Europe: Impacts of the crisis (Publications Office of the European Union, Luxembourg, 2012).

6. Impacts of the crisis (Publications Office of the European Union, Luxembourg, 2012).

7. R. Buckley, J. Kalarical, Housing policy in Developing Countries: Conjectures and Refutations (Oxford University Press, IBRD, The World Bank, 2005)

8. J. Smith, S., Elsinga, M., Fox O'Mahony, L., Ong, S. E., Wachter, S. és Hamnett, C. (eds.) International Encyclopedia of Housing and Home, Vol 3. (Oxford: Elsevier; 2012)

9. E. M. Marchenko, V. V. Glazkova, Assessment of efficiency of social innovative and investment projects. Monograph. (Vladimir, Transit ICKX, 2015)

10. V. V., Zozulya, L. I.Goncharenko, A. V.Zuikov, G. N.Semenova, Journal of Advanced Research in Law and Economics, 8(5), pp. 1629-1633 (2017)

11. E. Vasilyeva, MATEC Web of Conferences, 170, 01050 (2018)

12. R. Hunt, Strategic management, 3, 46-48 (2011) 